Article

\title{
The Social Dimension of Sustainable Neighborhood Design: Comparing Two Neighborhoods in Freiburg, Germany
}

\author{
Bjoern Hagen *, Cara Nassar and David Pijawka \\ School of Geographical Sciences \& Urban Planning, Arizona State University, Tempe, AZ 85287-5302, USA; \\ E-Mails: bhagen1@asu.edu (B.H.), cnassar@asu.edu (C.N.), pijawka@asu.edu (D.P.) \\ * Corresponding author
}

Submitted: 12 May 2017 | Accepted: 1 September 2017 | Published: 13 October 2017

\begin{abstract}
The study presented in this article adds to the body of research on the socio-cultural dimension of sustainable cities by looking at the efforts of the City of Freiburg, Germany to create neighborhoods that acknowledge the importance of the social dimension of sustainable development. The research in this article is centered on evaluating the social responses of living in Freiburg's two recognized sustainable neighborhoods Rieselfeld and Vauban. The study focuses on the motivational factors that prompted todays residents of the two neighborhoods to move there in the first place, their level of satisfaction living there now, and their perceived social interactions and level of community engagement. Results show that satisfaction with living in a place and reinforcing its assets through social resiliency or livability can result in longterm community staying power. In general, there were few differences in preference ratings of physical and social assets between the two communities. The levels of importance of social factors contributing to place satisfaction and staying power were not significantly different in both neighborhoods. Having a "cluster" of social factors present that were important to residents contributed significantly to place satisfaction. In fact, survey results showed that it was these social factors that were seen as more important to place satisfaction than the physical attributes of sustainable developments.
\end{abstract}

\section{Keywords}

Freiburg; social dimensions; social equity; survey research; sustainable community

\section{Issue}

This article is part of the issue "Social Ecology of Sustainability", edited by Stephen Wheeler (University of California, Davis, USA), Christina Rosan (Temple University, USA) and Bjoern Hagen (Arizona State University, USA).

(C) 2017 by the authors; licensee Cogitatio (Lisbon, Portugal). This article is licensed under a Creative Commons Attribution 4.0 International License (CC BY).

\section{Introduction}

The study presented in this article adds to the body of research on the socio-cultural dimension of sustainable cities by looking at the efforts of the City of Freiburg, Germany to create neighborhoods or communities that acknowledge the social dimensions of sustainable development and strengthening social ecology by building robust social systems that ultimately lead to stronger and more resilient communities (Wheeler, 2012). The City of Freiburg is located in the Southwest corner of Germany, at the edge of the Black Forest, and very close to the borders of Switzerland and France. The city (population of approximately 225,000 ) is today a hub for regional ecotourism and center for academia and research (City of Freiburg, 2017a). Over the last few decades, Freiburg focused heavily on becoming a recognized "green" and sustainable city and has won various national and international environmental awards for their policies and developments. Freiburg is especially well known as a green city or eco-city for its efforts in public transportation, alternative energy systems, and sustainable place-making (Newman, Beatley, \& Heather, 2009). The city administration emphasizes other sectors as well to increase the level of sustainability such as land conservation and the promotion of a green economy. The term eco-city represents 
a relatively new planning paradigm combining different societal aspects of urban development into a holistic political strategy built on consensus (Mössner, 2016). According to Roseland, the aim of eco-cities is "to secure the means to survival, improve the quality of community life, protect the environment and make inclusive and participatory decisions" $(2012$, p. 3).

Motivated by growing concerns over climate threats, environmental deterioration, social justice issues, and lack of economic opportunities, there are increased efforts worldwide to engage in more sustainable development practices, especially at the city level. Sustainable developments can be understood as efforts to increase the standard of living and thus quality of life, protect and enhance the natural environment, and preserve local culture and history (Deakin, 2001). Because of increased and ongoing efforts of city governments to find solutions to today's sustainability challenges (Luederitz, Lang, \& Von Wehrden, 2013), the concept of sustainable community development (Van der Ryn \& Calthorpe, 1986) has attracted attention by policymakers and academics alike, acknowledging the local community as an important unit of social organization and implementation of sustainability strategies (Dempsey, Bramley, Power, \& Brown, 2011). Communities are also beginning to employ sustainability officials to help them track their efforts and inform sustainable development. Even though many cities, such as Seattle, San Francisco, and Boston in the United States, have launched significant sustainability programs, there is often a lack of focus on social justice and equity concerns. Instead, sustainable development projects often pay less attention to the social dimension relative to the environmental and economic side of sustainability (Murphy, 2012). This may be because social well-being within the context of sustainability is often ambiguous and multifaceted with major methodological and theoretical complexities.

The Rieselfeld and Vauban developments stand out in public discussion and academic literature on Freiburg's efforts to become a more sustainable city. They are considered "eco-neighborhoods" (Scheurer \& Newman, 2009) with different interpretations and ideologies of sustainable community development as well as size and planning approaches. Both are highly regarded for their holistic sustainability planning with a strong focus on social aspects during the development process. Furthermore, both were planned and built during the 1990s and early 2000s, when Freiburg was experiencing a substantial housing shortage resulting in increased costs of living within the city and rapid suburbanization. The research presented in this paper is centered on evaluating the nature of social responses of living in the two neighborhoods. In both cases, the neighborhood development process was not exclusively guided by design, transportation, and ecological concepts, but also by a social concept acknowledging the need for "community" and social engagement.

In the wake of an increased focus on climate and environmental quality in the sustainable planning literature,
Dixon (2012) points to the real danger that the social dimension of sustainability will receive even less attention in the future. Already, decision-makers too often focus only on technical aspects such as energy reduction and efficiency, sustainable building materials, or compact settlement structures without acknowledging the importance of building social capital or social networks (Mössner, 2016). However, as research in the United Kingdom shows (Social Analysis and Reporting Division Office for National Statistics, 2001; Woodcraft, Hackett, \& CaistorArendar, 2011), social sustainability and its focus on community issues should be a central concern of all neighborhood developments. Without increasing social capital and well-being, successful sustainability policy may not be possible. For example, social well-being policies require enhanced public participation, acceptance, and support for mitigating and adapting to environmental threats such as climate change and other hazards (Hagen, Middel, \& Pijawka, 2016). Thus, social support and engagement is important in establishing sustainable practices. Unfortunately, much of the literature has focused primarily on environmental and economic issues, in part due to the "conceptual chaos" undermining the utility of the term "social" (Vallance, Perkins, \& Dixon, 2011), how to measure it, and a perceived trade-off at a global scale between social progress and environmental concerns (Colantonio \& Dixon, 2011; Holden, 2012).

Thus, adding to the social dimension and building social capital or social networks have become recognized as important factors in sustainable developments and community plans. This paper provides insights on the importance of the social dimensions of sustainable places and experiences based on visits to the two neighborhoods; interviews with architects, city planners, and community leaders in 2014; and surveys of the residents of Vauban and Rieselfeld in early 2017. Research was guided by the following underlying questions:

- How did the city of Freiburg establish social dimensions of neighborhood development into the planning process of Rieselfeld and Vauban to achieve sustainable communities?

- How do the residents perceive the level of social engagement in the two neighborhoods, why did they move there, and are they satisfied with their decision?

The article first discusses important literature in the area of sustainable social development. This is followed by a description of Freiburg's approach of becoming a more sustainable city and of the two neighborhoods of Rieselfeld and Vauban which are the focal point of this study. The third part introduces the methodology of this study, particularly the survey instrument, data collection process, and the applied statistical analysis. Section four presents the analysis of the survey data focusing on the motivational factors that prompted todays residents of Rieselfeld and Vauban to move there in the first 
place, their level of satisfaction living there now, and their perceived social interactions and level of community engagement.

\section{Literature Review}

\subsection{Theoretical Background}

The idea of sustainable development was conceptualized in the 1980s in a time of increasing awareness of ecological issues and an ongoing "retreat from social concerns" (Dempsey et al., 2011). Ecological devastation and the lack of social equity concerns manifested itself in many parts of the world in forms of poverty, deprivation, and urban dereliction (Carley \& Kirk, 1998). Today, the most accepted definition of sustainable development was provided in 1987 by the World Commission on Environment and Development (1987) in its report 'Our Common Future'. Often referred to as the Brundtland Report, the definition emphasizes our responsibility to future generations and describes sustainable development as balancing economic, environmental, and social concerns. However, the balancing of the underlying aspects of sustainable development are not without conflicts and have led to different urban forms that claim to be sustainable (Giddings, Hopwood, \& O'Brien, 2002; Jenks \& Dempsey, 2005). Generally speaking, the preferred urban form from a sustainability urban planning perspective is characterized by high degrees of compactness and density as well as mixed use with public transportation and use of sustainable materials. However, many argue that the sustainability benefits of compact forms are still contested and robust data that supports the claims are deficient (Bramley \& Power, 2009).

Nonetheless, since the conceptualization of sustainable development, different approaches have emerged that highlight distinctive aspects of a sustainable urban neighborhood. For example, the work by Ahmed (2012) presents the efforts of neighborhoods in the United Arab Emirates to excel in social aspects and Li, Wang, Paulussen and Liu (2005) discuss Beijing's strategy to improve urban greening while considering ecological principles. Other approaches focus on the cultural dimension (Joubert, 2004), economic stability (Jones, Leishman, \& MacDonald, 2009), or determining thresholds and barriers to achieving sustainable neighborhoods. (Galster, Quercia, \& Cortes, 2000). Given the fact that current definitions of sustainable development place responsibility on humans (Hopwood, Mellor, \& O'Brien, 2005), it is surprising how little attention has been placed on clearly defining social sustainability and its relationship to the built environment. As mentioned before, there is a relatively small body of literature that focuses specifically on social sustainability.

Similar to the concept of sustainable development, social sustainability is not an absolute or a constant (Dempsey et al., 2011). Instead it is a dynamic and multidimensional concept that changes over time and holds various theoretical constructs. However, the underlying question of what social goals of sustainable development are and a clear understanding of how to meet those goals is still up for debate (Hopwood et al., 2005; Littig \& Griessler, 2005). Even though the social dimension of sustainability is widely accepted as a key aspect of sustainable development, it has not been clearly conceptualized and only a few efforts to define social sustainability exist (Bramley \& Power, 2009; McKenzie, 2004; Stren \& Polèse, 2000; Yiftachel \& Hedgcock, 1993). Little attention has been given to the social sustainability factors at the community level. This lack of a clear definition and meaning of social dimensions everybody can agree on is happening despite recent efforts in Europe through the 'Bristol Accords' (UK Presidency, 2005) and 'Leipzig Charter' (Bundesministerium für Umwelt, Naturschutz, Bau und Reaktorsicherheit, 2007) which outline a common approach to and characteristics of sustainable neighborhoods for all European Union (EU) members including social-livability factors. The work on social dimensions of sustainability presented is this paper is based on a definition provided by Stren and Polèse (2000, pp. 16-17) who defined the social dimensions of sustainable development in an urban planning context as "development (and/or growth) that is compatible with the harmonious evolution of civil society, fostering an environment conducive to the compatible cohabitation of culturally and socially diverse groups while at the same time encouraging social integration, with improvements in the quality of life for all segments of the population."

In the context of this study's focus on the sociocultural dimensions of sustainable urban development, we understand social sustainability as the means to create strong, vibrant, and healthy communities that enhance the quality of life and the overall resiliency of the neighborhood and its population. Establishing a built environment of high quality provides accessible local services that contributes to the overall physical, social, and cultural well-being. It is important to gain a practical understanding of social sustainability and operationalize it, especially in times of rapid urbanization with increased housing needs and declining public resources to ensure strong and resilient communities (Department for Communities and Local Government, 2012; Woodcraft, 2012).

A key component of social sustainability is the concept of social justice and equity with different approaches (Agyeman, 2005; Harvey, 2010; Fainstein, 2010) to fair allocation of resources, inclusiveness, as well as full and equal accessibility to all aspects of society (Dempsey et al., 2012). The level of accessibility to local amenities plays a key role in establishing a socially just community (Barton, 2000a; Burton, 2000). Ensuring residents' ability to access services and opportunities such as parks within the community assigns physical neighborhood planning an important role. A thoughtfully planned settlement structure can shorten travel distances, improve walkability and, improve access to pub- 
lic transit which allows all income classes access to economic opportunities as well as other local amenities that improve the quality of life (Hamiduddin, 2015). Local amenities can affect the well-being and increase social cohesion by covering daily functional needs, enabling incidental encounters between residents which in turn can improve social relations (Bridger \& Luloff, 1999). Moreover, social sustainability also implies local empowerment in decision-making and inclusivity in participation.

Among the important features residents need in terms of equitable access to everyday life are facilities for education and employment training, decent housing, public services, social infrastructure, green spaces, and cultural and recreational services (Dempsey et al., 2011). Some of these are directly linked to the built environment, whereas others are more indirect. Directly linked features are those that provide services and facilities or the means of accessing them, such as public transport. Indirectly linked features are those that are more abstract or intangible such as decent housing and social infrastructure.

A sustainable community is also strongly related to social cohesion and capital, which in turn is based on trust and social relationships among residents, public participation in community institutions, community stability and safety, and sense of community identity and belonging (Forrest \& Kearns, 2001; Hamiduddin, 2015). Currently, there is an increasing belief among policymakers and scholars alike that a large amount of social capital present in a community will allow the implementation of voluntarist solutions to problems that market mechanisms as well as government programs or legislation cannot address adequately (Flora, 1998). However, this hypothesis has not been tested sufficiently and conceptual issues remain that present a barrier to fully linking the successful development of a sustainable community to social capital.

Finally, a study by Bramley and Power (2009b) shows that sustainable urban forms can result in trade-offs between social equity and sustainable community elements, which need to be considered by policy-makers and urban planners. For example, the study shows that compact neighborhoods can exacerbate existing problems and dissatisfaction within the community, while si- multaneously improving access to services. Social cohesion and capital within a community improves its adaptive capacities regarding threats such as crime and environmental disasters (Seidman, 2013). In turn, overcoming threats to a community further improves social ties, sense of place, and overall happiness. However, the relationship between resiliency and social well-being needs further examination.

To better understand how urban form impacts social well-being, one needs to take a closer look at specific services and facilities at the neighborhood scale. An empirical study by Winter and Farthing (1997) points to eight services and facilities that, if locally available, are used most often and therefore represent important aspects to improve social relations and equity among the residents. These services and facilities are food shops, newsstands, open spaces, post offices, primary schools, bars, supermarkets, and secondary schools. Other theoretical studies argue that it is important that residents also have local access to doctors, restaurants and cafes, banks, and a community center (Aldous, 1992; Burton, 2000; Barton; 2000b). Finally, Dempsey et al. (2011) identified vital non-physical and physical factors that contribute to socially sustainable communities (Table 1 ).

The work of Dempsey et al. $(2011,2012)$ and this paper's underlying general definition of social sustainability by Stren and Polèse (2000) led to the development of a new framework to examine different elements of urban form on different factors of social sustainability. This framework identifies social justice and equity as core principles underlying social sustainability (Bramley, Dempsey, Power, \& Brown, 2009; Hamiduddin, 2015). The study presented in this paper does not address all factors outlined in Table 1. Instead it focuses on factors that can be captured and discussed based on data provided by the study's survey instruments, site visits to Freiburg including the Rieselfeld and Vauban neighborhoods, and conducted interviews. These factors include: 1) socialcapital, -networks, and -interactions; 2) participation and active community organization; 3 ) quality of life and wellbeing; 4) sense of community and belonging; 5) accessibility; 6) sustainable urban design (i.e. energy efficiency, car-free zones) and 7) walkability.

Table 1. Contributing factors to urban social sustainability.

\begin{tabular}{ll}
\hline Non-physical factors & Predominantly physical factors \\
\hline - Education, training, \& cultural traditions & - Urbanity \\
- Social-justice, -inclusion, -capital, -order, -cohesion, -networks, & - Attractive public realm \\
-interaction & - Decent housing \\
- Participation, local democracy, \& active community organization & - Local environmental quality and amenity \\
- Health, quality of life, \& well-being & - Accessibility \\
- Community, community cohesion, sense of community and belonging & - Sustainable urban design \\
- Safety, employment, residential stability, mixed tenure, fair & - Neighborhood \\
distribution of income & - Walkability \\
\hline
\end{tabular}

Note: Adapted from Dempsey et al. (2011). 


\subsection{City of Freiburg}

Much has been written about Freiburg's efforts to become a green or eco-city. This article does not go into the details due to the vast amount of literature already available (Crowhurst Lennard, von Ungern-Sternberg, \& Lennard, 1997; Drilling \& Schnur, 2012; Frey, 2013; Medearis \& Daseking, 2012). Instead the following will provide a brief history of the city efforts to become more sustainable with a focus on factors contributing to the social dimensions of sustainability. First, it is important to understand the city's environmental history and how that has led to strong public support for sustainable development initiatives today.

Due to a large academic community in the city, Freiburg became a center for the country's green movement in the 1970s. In 1975, a proposed nuclear power plant close to the city sparked significant citizen protest and Freiburg citizens successfully defeated the project (Nössler \& de Witt, 1976). Many protest leaders and other people involved in Freiburg's green movement remained in the area after obtaining their educational degrees and became involved in local and regional politics, found employment in educational or research activities, or founded environmentally-based companies. Although critics point out the lack of evidence for a direct connection between the protests in the 1970s and today's strong focus on sustainable development and clean energy in Freiburg (Mössner, 2015), according to Thomas Dresel from Freiburg's Environmental Protections Agency "the mid 1970s is when it all started" (Dresel, personal communication, July 2014). This is echoed by the literature (Medearis \& Daseking, 2012; Rohracher \& Späth, 2014) that describe this time period as an important milestone in Freiburg's history as an eco-city, impacting the political landscape of the city and allowing city officials to commit to long-term sustainable development goals, especially in regards to increasing the city's renewable energy portfolio. The history of the green movement in Freiburg with a strong citizen participation as well as the city's early focus on clean energy and improving public transit has also contributed to the social dimension of sustainability in the city, fostering contributing factors such as social-capital, participation and active community organization, and sustainable urban design.

In the following years, Freiburg became increasingly more environmentally active and acknowledged the need to engage in sustainable development before the term gained popularity after the 1992 UN Earth Summit in Rio de Janeiro, Brazil. By 1986, Freiburg became one of the first cities in Germany to establish an Environmental Protection Agency. The City also passed a local energy supply concept to promote energy conservation, climate protection and a withdrawal from nuclear energy the same year. Another key year was 1996, in which the city drafted its own local Agenda 21, setting the framework and goals for various sustainability activities and projects (City of Freiburg, 2017b). In 2006, Freiburg signed the Aal- borg Commitments which provides a common format for the promotion of energy conservation, climate protection, sustainable urban development and an expanded public awareness of environmental issues in European cities (Frey, 2013). In addition, the City developed its own climate action plan in 2007.

According to the mayor Dieter Salomon, Freiburg's success in moving towards an eco-city is a result of a long-term and strategic approach to urban planning, the advancing of environmentally friendly businesses, strong public participation and support for sustainable policies, and a proactive city government (Frey, 2013). Public participation in the decision-making process is identified as a key component for the success of a sustainable community development project and is also an important nonphysical factor to urban social sustainability, as outlined in Table 1. Often, successful interventions due to sustainability concerns or new approaches to community development result from public engagement that are not possible from traditional top-down strategies (Bridger \& Luloff, 2001). Instead, the knowledge and efforts of people familiar with local circumstances is essential. In addition, Thomas Dresel points to the "five big Cs" that are preconditions for successful sustainable policy implementation and urban development in Freiburg (Dresel, personal communication, July 2014). The five Cs stand for "cost, comfort, control, consensus, and cooperation" which also relate to several contributing factors to the social dimensions of sustainability, such as sense of community and belonging, quality of life and well-being, participation, or social interaction. From a citizen perspective, sustainable policies are more likely to be supported if extra costs are reasonable and do not increase beyond $10 \%$ (i.e. energy or building material); they do not decrease the comfort of living and acknowledge current lifestyles; and they are implemented in a very transparent form providing the public with a sense of control over costs and spending. From a municipal policy perspective, it is crucial that policies are based on a broad consensus and cooperation within the city government as well as between the government and the public.

Because of careful planning, transparency in the decision-making process, and comprehensive public outreach, a considerable number of Freiburg's residents support the city's approach towards designing and implementing sustainable development strategies (Hopwood, 2007). Thus, it is not surprising that the current mayor, who has been in office since 2002, is a member of the Green Party. The Green Party also holds the most seats in the city government with 11 out of 48 seats (City of Freiburg, 2017c). Work by Mössner suggests that Freiburg successfully "arranged a whole 'eco-system' of techniques, markets and politics that set new standards for implementing sustainability at the local level and in all societal fields, seemingly including all parts of society" (2016, p. 973).

Parallel to the environmental movement in Freiburg, a housing-related social movement developed as well 
in the early 1980s. Ongoing population migration to Freiburg and other cities sparked a housing crisis, pricing especially younger residents out of the market and forcing them to occupy vacant houses do to the lack of affordable housing stock. This led political decision-makers to focus more on affordable housing throughout the city, emphasizing affordable housing and other social equity objectives in their initial planning and early construction phases. This focus was very apparent in the development phases of both Rieselfeld and Vauban.

\subsection{Rieselfeld and Vauban}

Of these two recent neighborhood developments in Freiburg, Rieselfeld can be considered the result of a long-term planning approach by the city to provide new housing, whereas Vauban was the outcome of an unexpected availability of land in the form of an abandoned French army barracks. Rieselfeld can be characterized as an exurban scheme designed with greater self-containment in mind, with a full range of schools and community infrastructure, compared to the smaller Vauban neighborhood. Construction of Rieselfeld began in 1994 and was completed in 2010. The first residents moved there in 1996 and today Rieselfeld's 4,500 housing units can house up to 12,000 people (Frey, 2013). The development phase of Vauban also began in 1994 with its first residents moving into the neighborhood in 1998. By 2006, the neighborhood was fully developed and today is home to about 5,500 people (Forum Vauban, 2017).

The built environment is similar in both neighborhoods. As shown in Figures 1 and 2, Rieselfeld and Vauban have significant car free areas, green infrastruc- ture and networks, and a superblock pattern with low mobility needs and high walkability supporting social interactions and health among residents. Both neighborhoods were also connected to light rail and bus networks early on, linking the new developments to the downtown and commercial districts of Freiburg. Both communities were designed to reduce the use of the private automobile, but Vauban implemented more stringent measures. Whereas parking is available throughout Rieselfeld, Vauban established car-park-free housing requiring car owners to purchase a parking spot in structures located on the edges of the neighborhood. Car owners also had to cover the costs for building the parking structures, amounting to approximately $€ 18,000$ per car.

In both cases, the design of the neighborhoods has been profoundly impacted by public participation and strong city government involvement that controlled the development process from the outset rather than private developers (Hamiduddin \& Daseking, 2014). Instead of selling an entire site to a developer, the local government favored an alternative approach, making individual parcels available for collaborative self-build development, so called "Baugruppen", or co-operative building. Within an overall framework of design codes and with the help of an assigned architect, the cooperative housing approach allowed future residents of Vauban and Rieselfeld to collaborate on financial and design aspects of an apartment building and ensure that the requirements of all households were met. Proponents of this approach emphasize its benefits, including meaningful public input into the design and construction process, fostering social bonds from the onset of a project, and significant cost savings compared to traditional and developer-driven individual housing projects (Barlow, Jackson, \& Meikle, 2001).

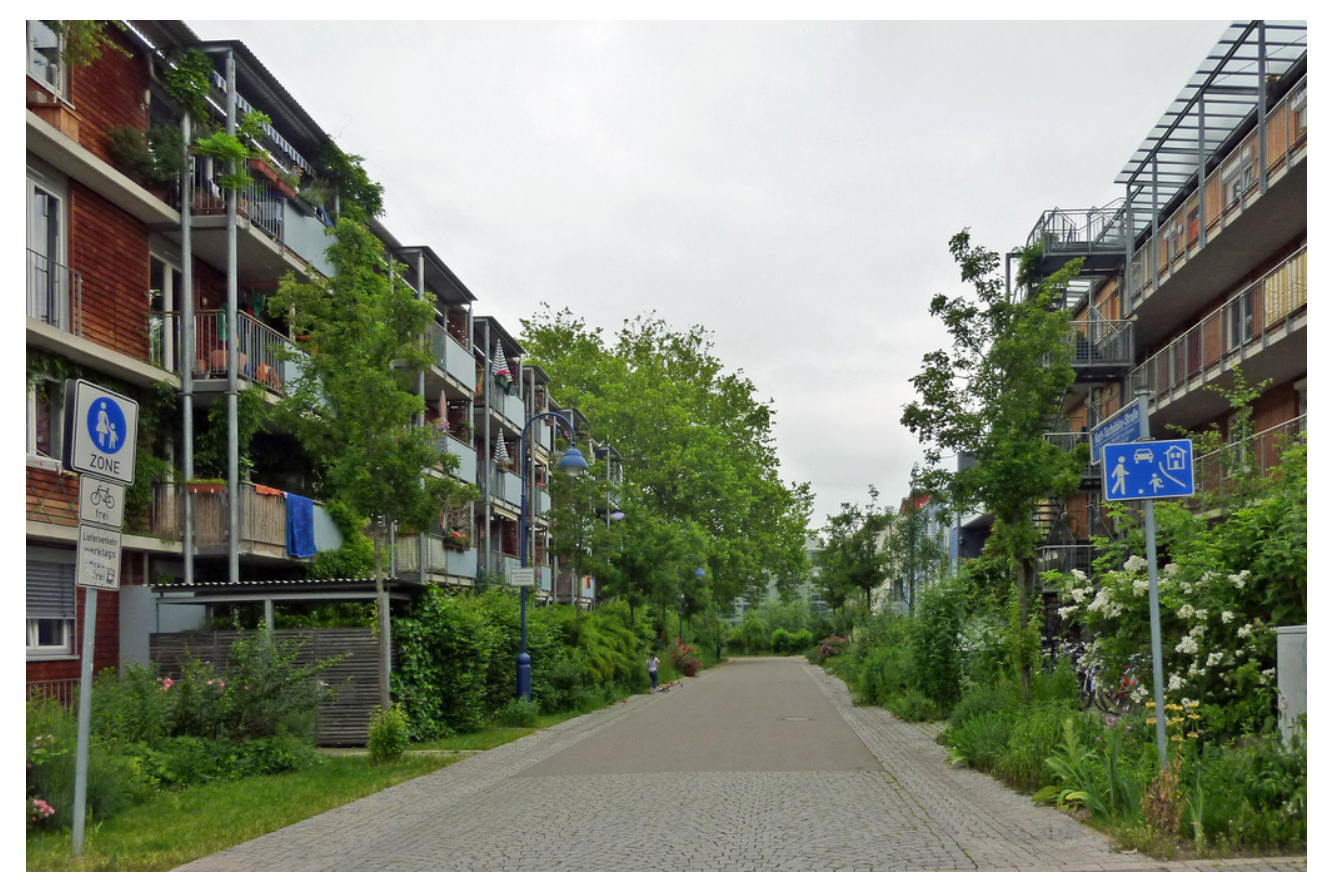

Figure 1. Vauban housing court in 2011 (Payton Chung, Flickr). 


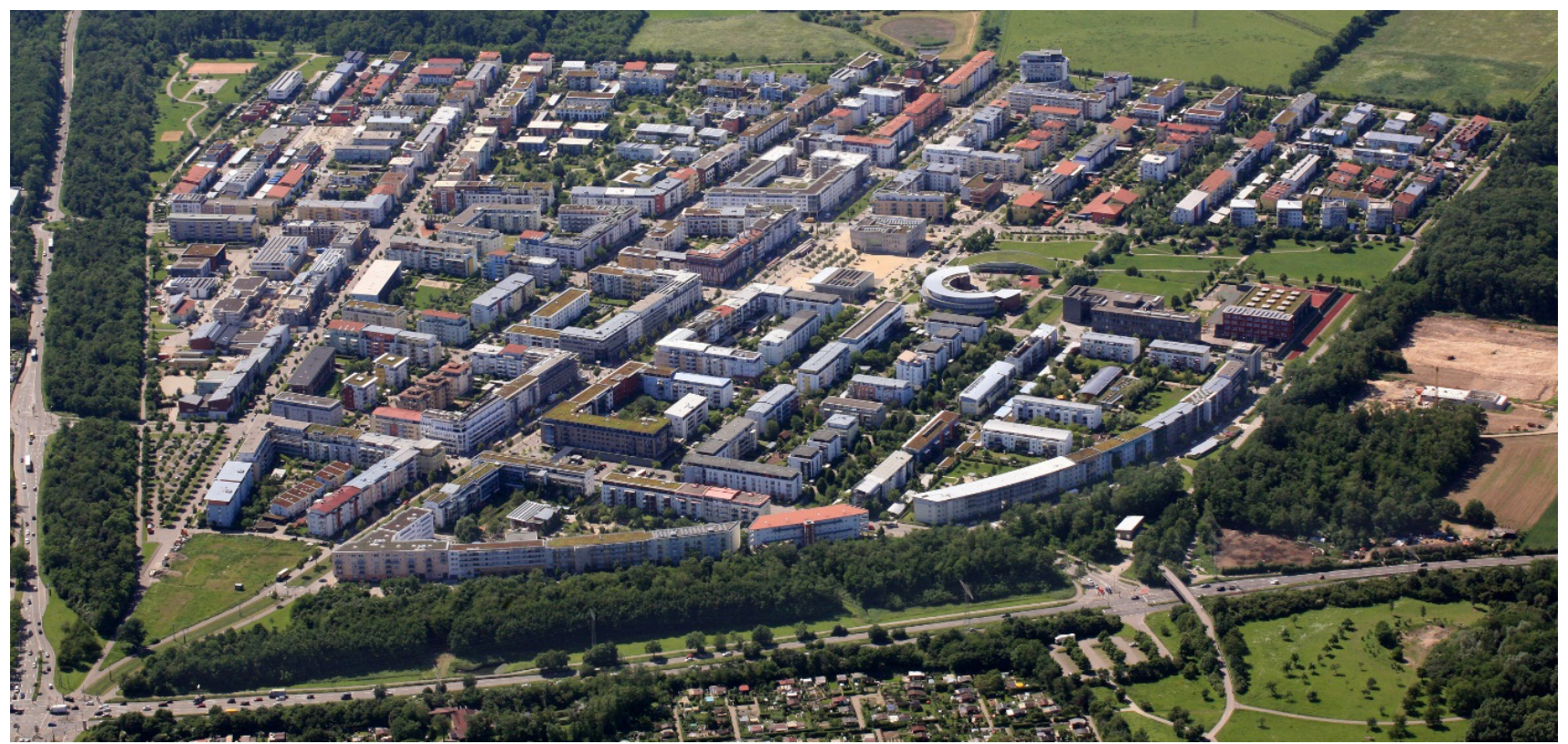

Figure 2. Aerial view of Rieselfeld neighborhood in 2012.

Rieselfeld also applied a "responsive" planning approach to the neighborhood development under the leadership of Klaus Siegel, the head of the city-appointed Rieselfeld Development Committee from 1992 to 2010 (Siegel, personal communication, July 2014). Development was split into four distinct property segments with each development starting 2 years after the previous section. This allowed a flexible planning approach that could learn from mistakes and adapt to changes in the demographics and needs of households interested in living in Rieselfeld.

Regarding the social dimension of neighborhood design and the first research question of this paper, the work done in Rieselfeld and Vauban emphasizes two factors that strongly contribute to sustainable and socially just communities (Hamiduddin, 2015). First, neighborhood development allows for a co-operative housing development model as well as easy accessibility to a comprehensive public transit system that makes it easier for young families as well as lower income groups to relocate there. Second, neighborhood design favors pedestrians and cyclists over the car as well as provides ample green space and a high-quality public realm for children to play and adults to interact with each other. These factors enhance social relations among the residents.

In addition, both neighborhoods established citizen organizations early on, such as K.I.O.S.K (Contact, Information, Organization, Self-Help, and Culture) and BIV (Citizens Association) in Rieselfeld, and the Stadteilverein Vauban e.V. (Neighborhood Citizen Club) in Vauban. According to Andreas Rössler (president of BIV and longterm resident of Rieselfeld) and Almut Schuster (member of Stadteilverein Vauban e.V and long-term resident of Vauban), the early installment of citizens' organizations was crucial in the overall success of both neighborhoods and building up a strong sense of place and community as well as a robust and diverse social fabric (Rössler \& Schuster, personal communication, July 2014). These institutions provided an opportunity for residents to provide feedback on proposed designs and policies, and encouraged social interaction early on. Fostering citizen involvement from the beginning created a strong sense of identity and responsibility among today's residents. People who live in in either of two neighborhoods generally care about the environment and value the social infrastructure and networks they helped to put in place so many years ago.

\section{Methodology}

The data presented and discussed in the following section were gathered through surveys conducted in the two neighborhoods over a three-week period in January 2017. Rieselfeld and Vauban residents were asked to fill out a survey instrument containing 27 questions. In total, 200 completed surveys were collected, 103 in Vauban and 97 in Rieselfeld. The two neighborhoods were chosen because of the present social sustainability conditions discussed. All streets and homes were selected at random, and responses were collected on a voluntary basis with complete anonymity. The surveys were either filled out with the collector present or distributed and collected later. The researcher conducting the fieldwork underwent training prior to the fieldwork to ensure that participants were not influenced, were at least 18 years of age, and that privacy rights were protected. Table 2 shows the characteristics of the two neighborhood survey samples with respect to gender, age group, children per household, time of residency, and living situation.

Randomization techniques were used in the collection of the survey data. Participants were approached on the street or at home and asked to participate in the 
Table 2. Characteristics of surveyed population.

\begin{tabular}{|c|c|c|c|c|c|c|c|}
\hline Gender & Female & Male & No Answer & & & & \\
\hline Rieselfeld & $51.6 \%$ & $44.3 \%$ & $4.1 \%$ & & & & \\
\hline Vauban & $53.4 \%$ & $44.7 \%$ & $1.9 \%$ & & & & \\
\hline Age Groups & 18 to 24 & 25 to 34 & 35 to 44 & 45 to 54 & 55 to 64 & $65+$ & No Answer \\
\hline Rieselfeld & $8.2 \%$ & $4.1 \%$ & $10.3 \%$ & $50.5 \%$ & $19.6 \%$ & $5.2 \%$ & $2.1 \%$ \\
\hline Vauban & $14.6 \%$ & $1.9 \%$ & $5.8 \%$ & $43.7 \%$ & $21.4 \%$ & $7.8 \%$ & $4.6 \%$ \\
\hline Children per household & 0 & 1 & 2 & 3 & $4+$ & Mean & \\
\hline Rieselfeld & $33.0 \%$ & $24.7 \%$ & $27.8 \%$ & $11.3 \%$ & $3.1 \%$ & 1.3 & \\
\hline Vauban & $46.6 \%$ & $20.4 \%$ & $23.3 \%$ & $8.7 \%$ & $1.0 \%$ & 1.0 & \\
\hline Time living in... & $1<$ years & $1-3$ years & $4-6$ years & $7-9$ years & $10+$ years & & \\
\hline Rieselfeld & $5.2 \%$ & $5.2 \%$ & $5.2 \%$ & $15.5 \%$ & $69.1 \%$ & & \\
\hline Vauban & $4.9 \%$ & $9.7 \%$ & $7.8 \%$ & $5.8 \%$ & $71.8 \%$ & & \\
\hline Living Situation & Rent & Own & No Answer & & & & \\
\hline Rieselfeld & $12.4 \%$ & $85.5 \%$ & $3.1 \%$ & & & & \\
\hline Vauban & $24.3 \%$ & $68.9 \%$ & $7.0 \%$ & & & & \\
\hline
\end{tabular}

Note: In total, 200 completed surveys were collected, 103 in Vauban and 97 in Rieselfeld.

15-minute survey. It is important to acknowledge here that several factors may have influenced the survey data. The researcher administering the survey and collecting data was not a native German speaker. Potential survey participants were approached in English, but were provided with a survey instrument and information sheet about the study in German to reduce survey bias. Although translations were provided and younger generations learn English in school, language barriers between the researcher and elderly people may have affected survey response rates among this age group. However, enough household responses were obtained from the two neighborhoods to be able to scientifically generalize for each neighborhood.

Originally developed for risk perception research, the survey research presented in this paper is based on a psychometric paradigm (Fischhoff, Slovic, Lichtenstein, Read, \& Combs, 1978; Slovic, Fischhoff, \& Lichtenstein, 1984), which assumes that through appropriate survey design, different scaling methods, and multivariate analysis of public attitudinal, motivational and behavioral factors important to this study can be captured. The survey questions and response items are based on previous studies in public perceptions and community research (McMillan \& Chavis, 1986; Nasar \& Julian, 1995; Sander, 2002; Schwaller, 2012). The majority of questions in the survey were closed-ended, multiple-choice questions, allowing easy coding and comprehensive statistical analysis (Henerson, Morris, \& Fitz-Gibbon, 1987). The questions asked were predominantly focused on the motivating factors of moving to either Rieselfeld or Vauban, the level of satisfaction of living in the two neighborhoods, and social engagement factors as well as socio-economic information shown in Table 2 . The survey questions were designed with the seven contributing factors of social sustainability outlined in section 2.1 in mind.

The questions mainly consisted of "Likert-type scaling" and answers were balanced equally. This means that the number of favorable and unfavorable answer categories are equal to prevent statistical biases. The Likertscales used in the survey instrument were mostly 5- to 7-point scales. The answers ranged, for example, from strongly disagree to strongly agree or from unimportant to very important with a neutral answer possibility. The survey instrument was tested and reviewed by national researchers experienced in survey research, public engagement, and community planning to ensure the validity of the Likert-scales and other multiple-choice questions. The total sample size of 103 households for Vauban and 97 for Rieselfeld is large enough to generalize results with a $95 \%$ confidence level at $\pm 4 \%$ margin of error for both neighborhoods. This study applied basic statistical methods such as frequency distributions and descriptive statistics.

\section{Data Analysis}

\subsection{Motivational Factors for Moving to Rieselfeld and Vauban}

To understand why people decided to move to Rieselfeld or Vauban, one set of survey questions targeted the underlying motivation and reasons to relocate to either neighborhood. Our hypothesis was that potential residents of the two neighborhoods were motivated by sustainability as they were provided with plenty of information on how the communities would be centered on sustainable design, including social infrastructure acknowl- 
edging the social dimension of sustainability. The study was interested in 1) discerning what factors were important in the decision to purchase a home in either of the neighborhoods and the relative weights of those factors; and 2) were these factors aligned with the prevailing literature on social sustainability and neighborhood social well-being factors leading to happiness (Choi, 2013; Cloutier \& Pfeiffer, 2015). Data collected also allows us to examine if the motivational factors to relocate were aligned with the advertised amenities of the communities during the planning and development process as well as to determine whether today's level of satisfaction of living in the two neighborhoods can be accounted for by the reasons prompting the move in the first place.

The survey asked respondents how important a set of nine factors were in deciding to move to a neighborhood designed along new urbanism and sustainable design principles. These factors were Safety, Peace \& Quiet, Affordability of Housing, Quality of Schools, Sense of Community, Walkability, Energy Efficiency Households, Public Amenities, and Environmentally Friendly Design. The nine factors were chosen based on the work by Sander (2002) and Schwaller (2012) to permit data comparison of similar neighborhoods at a later stage of this project. In addition, the chosen factors address various indicators of social sustainability in an urban environment discussed in section 2.1 such as sense of community, sustainable urban design, accessibility, quality of life, and walkability. Table 3 shows the mean scores and percentages for each factor by neighborhood.

The results show that the top two factors for relocation are the same for both neighborhoods. The prospect for "Peace \& Quiet" was the most important factor for relocation with a mean score of 5.4 in Rieselfeld and a 5.7 in Vauban. This was followed by "Environmentally Friendly Design" with mean scores of 5.3 and 5.6, respectively. Both these factors include sub-factors such as utilization of solar technology, high density dwellings, green open space, pedestrianism, and nearby schools. "Energy Efficient Households" was ranked third by Rieselfeld participants with a mean score of 5.2. In Vauban, this was ranked fourth, with a mean score of 5.4, behind "Walkability" with a mean score of 5.5.

In reviewing the data, a couple of interesting trends emerge. First, nearly all factors received points on the higher side of the scale, meaning that all factors had some importance in the decision to relocate. However, environmental factors dominated. Second, we hypothesized that household composition and number of children account for relatively large differences between neighborhood rankings for "Public Amenities" and the "Quality of Schools" factors when compared to the other seven aspects. Almost $50 \%$ of all households in Vauban do not have children compared to only one-third in Rieselfeld. Furthermore, each household in Rieselfeld has on average 1.3 children; in Vauban, the number is 1.0. In addition to "Public Amenities" and "Quality of Schools", "Walkability" mean scores ranked differently as factors for moving to Rieselfeld or Vauban. For all three factors t-tests show a statistically significant difference between the two samples with $p \leq 0.05$.

"Public Amenities" was the factor with the largest difference in mean scores. It averaged 5.0 in Rieselfeld (ranking $5^{\text {th }}$ ) and 4.3 in Vauban (ranking $6^{\text {th }}$ ). In other

Table 3. Level of importance of different factors for moving to Rieselfeld or Vauban

\begin{tabular}{|c|c|c|c|c|c|c|c|c|c|}
\hline Rieselfeld & 1 & 2 & 3 & 4 & 5 & 6 & 7 & Mean & Rank \\
\hline Safety & $20.6 \%$ & $12.4 \%$ & $10.3 \%$ & $20.6 \%$ & $16.5 \%$ & $11.3 \%$ & $8.2 \%$ & 3.7 & 9 \\
\hline Peace \& Quiet & $3.1 \%$ & $3.1 \%$ & $7.2 \%$ & $6.2 \%$ & $23.7 \%$ & $33.0 \%$ & $23.7 \%$ & 5.4 & 1 \\
\hline Affordability of Housing & $8.2 \%$ & $11.3 \%$ & $13.4 \%$ & $22.7 \%$ & $12.4 \%$ & $18.6 \%$ & $13.4 \%$ & 4.3 & 8 \\
\hline Quality of Schools & $16.5 \%$ & $7.2 \%$ & $9.3 \%$ & $8.2 \%$ & $19.6 \%$ & $17.5 \%$ & $21.6 \%$ & 4.4 & 7 \\
\hline Sense of Community & $3.1 \%$ & $11.3 \%$ & $9.3 \%$ & $9.3 \%$ & $23.7 \%$ & $20.6 \%$ & $22.7 \%$ & 4.9 & 6 \\
\hline Walkability & $3.1 \%$ & $13.4 \%$ & $6.2 \%$ & $9.3 \%$ & $19.6 \%$ & $26.8 \%$ & $21.6 \%$ & 5.0 & 5 \\
\hline Energy Efficient Households & $4.1 \%$ & $6.2 \%$ & $5.2 \%$ & $12.4 \%$ & $24.7 \%$ & $21.6 \%$ & $25.8 \%$ & 5.2 & 3 \\
\hline Public Amenities & $2.1 \%$ & $6.2 \%$ & $7.2 \%$ & $20.6 \%$ & $13.4 \%$ & $35.1 \%$ & $15.5 \%$ & 5.0 & 4 \\
\hline Environmental Friendly Design & $5.2 \%$ & $3.1 \%$ & $4.1 \%$ & $13.4 \%$ & $17.5 \%$ & $35.1 \%$ & $21.6 \%$ & 5.3 & 2 \\
\hline Vauban & 1 & 2 & 3 & 4 & 5 & 6 & 7 & Mean & Rank \\
\hline Safety & $19.4 \%$ & $19.4 \%$ & $12.6 \%$ & $13.6 \%$ & $17.5 \%$ & $5.8 \%$ & $11.7 \%$ & 3.5 & 9 \\
\hline Peace \& Quiet & $2.9 \%$ & $3.9 \%$ & $1.0 \%$ & $10.7 \%$ & $13.6 \%$ & $35.0 \%$ & $33.0 \%$ & 5.7 & 1 \\
\hline Affordability of Housing & $17.5 \%$ & $13.6 \%$ & $11.7 \%$ & $8.7 \%$ & $23.3 \%$ & $9.7 \%$ & $15.5 \%$ & 4.0 & 7 \\
\hline Quality of Schools & $26.2 \%$ & $9.7 \%$ & $4.9 \%$ & $16.5 \%$ & $19.4 \%$ & $12.6 \%$ & $10.7 \%$ & 3.7 & 8 \\
\hline Sense of Community & $3.9 \%$ & $1.0 \%$ & $11.7 \%$ & $16.5 \%$ & $21.4 \%$ & $35.0 \%$ & $10.7 \%$ & 5.0 & 5 \\
\hline Walkability & $4.9 \%$ & $4.9 \%$ & $4.9 \%$ & $5.8 \%$ & $12.6 \%$ & $30.1 \%$ & $36.9 \%$ & 5.5 & 3 \\
\hline Energy Efficient Households & $6.8 \%$ & $1.0 \%$ & $4.9 \%$ & $11.7 \%$ & $12.6 \%$ & $35.0 \%$ & $28.2 \%$ & 5.4 & 4 \\
\hline Public Amenities & $10.7 \%$ & $6.8 \%$ & $11.7 \%$ & $20.4 \%$ & $15.5 \%$ & $30.1 \%$ & $4.9 \%$ & 4.3 & 6 \\
\hline Environmental Friendly Design & $5.8 \%$ & $1.0 \%$ & $5.8 \%$ & $4.9 \%$ & $16.5 \%$ & $35.9 \%$ & $30.1 \%$ & 5.6 & 2 \\
\hline
\end{tabular}

Note: Survey respondents were asked "On a scale from 1 to 7 , how important were each of the following items in your decision to live in Vauban/Rieselfeld, with 1 being 'not important at all' and 7 being 'you would not have relocated without it'?". 
words, public amenities were seen as more important in Rieselfeld. Less than $51 \%$ of respondents in Vauban identified them as an important relocation factor (4.9\%) compared to almost $65 \%$ in Rieselfeld (15.5\%), who identified them as essential to their decision to move to Rieselfeld. The second factor 'Quality of Schools' was also more important to residents in Rieselfeld than Vauban. Overall, it was one of the less important factors motivating people to move. However, the percentage of respondents indicating that without quality schools they would not have relocated is twice as high in Rieselfeld (21.6\%) compared to Vauban (10.7\%). The third factor "Walkability" was considered more important to the residents in Vauban compared to Rieselfeld. We hypothesize that Vauban's strong focus on car free living, compared to Rieselfeld that allows private cars at all times in its interior, is an important aspect that contributed to the difference between the two places regarding this factor.

Another set of questions asked about the relative importance of environmental and social factors in deciding whether or not to move into the neighborhood (Table 4). Overall, the response percentages show environmental factors were seen as "Somewhat important" to "Important" in both of the neighborhoods. In Vauban, this was $68.9 \%$; in Rieselfeld, it was $72.16 \%$. Environmental factors were significantly less important than social factors. For example, environmental factors averaged $12.9 \%$ as being 'very important' while social factors averaged $37.5 \%$. Social factors were seen as 'Somewhat important' to 'Important' in both of the neighborhoods with $69.9 \%$ of residents in Vauban and $73.2 \%$ of residents in Rieselfeld expressing this opinion.

It is important to note that the major relocation factors identified were also key points of the underlying concepts of the two neighborhoods developed by the city government with the help of planners, architects, and involved citizens (Frey, 2013) Moreover, major reasons for relocation such as Peace \& Quiet, Environment Friendly Design, Walkability, or Energy Efficient Households fall within the contributing factors of social sustainable neighborhood design identified in the literature and discussed in section 2 of this article. This suggests that early marketing campaigns were successful in attracting potential residents that were supportive of the underlying neighborhood concepts. However, a very important factor for the city of Freiburg in developing the two neighborhoods, "Affordability of Housing", ranked in the lower third ( $8^{\text {th }}$ in Rieselfeld and $7^{\text {th }}$ in Vauban) among all possible motivational factors for moving into either of the two neighborhoods. This is not totally unsurprising given the recent critiques of Freiburg's housing market as being not affordable (Hamiduddin, 2015; Mössner \& Miller, 2015).

Although providing affordable housing was one the key goals of Vauban and Rieselfeld, the overall success of Freiburg to become more sustainable has led to a considerable uptake in people wanting to move there and has led to lower income groups being priced out of the housing market. Due to the bidding mechanism of the open market, especially for residents in Vauban and Rieselfeld who were not among the original co-operative building groups, affordable housing was not an option and thus not a motivating factor in moving. Instead, critics argue that Rieselfeld and Vauban with their initial focus on social diversity have transformed over time into a relatively well to-do, homogeneous, ethnically German neighborhoods (Freytag, Gössling, \& Mössner, 2014). What does stand out as important are the motivational variables and physical features in terms of sustainable urban design and the social, mostly participatory, dimensions of the development process.

\subsection{Level of Satisfaction Living in Rieselfeld and Vauban}

Another group of questions focused on how satisfied residents are in living in Vauban or Rieselfeld. Since both neighborhoods have been completed for several years now, it is important to understand if today's residents are satisfied with the living conditions, social interactions, and public amenities. This will help inform similar future developments. The literature discussed in section 2 pointed out that several key factors-quality of schools, safety, local governance, social contacts, environmental quality, and housing conditions-are influential in creating neighborhood satisfaction or high levels of quality of life in neighborhoods. Survey questions were developed to measure the importance of several of these factors in determining the level of satisfaction in living in the two communities.

One question asked about the overall level of satisfaction of living in the two neighborhoods. As shown

Table 4. Importance of environmental and social factors for moving to Rieselfeld/Vauban.

\begin{tabular}{llllll}
\hline Environmental Factors & Not at all important & Somewhat important & Important & Very Important & No Answer \\
\hline Rieselfeld & $15.5 \%$ & $38.1 \%$ & $34.0 \%$ & $9.3 \%$ & $3.1 \%$ \\
Vauban & $13.6 \%$ & $35.9 \%$ & $33.0 \%$ & $16.5 \%$ & $1.0 \%$ \\
\hline Social Factors & Not at all important & Somewhat important & Important & Very Important & No Answer \\
\hline Rieselfeld & $2.1 \%$ & $13.4 \%$ & $35.1 \%$ & $38.1 \%$ & $2.6 \%$ \\
Vauban & $1.9 \%$ & $11.7 \%$ & $33.0 \%$ & $36.9 \%$ & $1.9 \%$ \\
\hline
\end{tabular}

Note: Survey respondents were asked "On a scale from 1 to 4 to what degree did the following factors enter into your decision to move to Vauban/Rieselfeld, with 1 being 'not at all important' and 4 being 'very important'?". 
in Table 5, the results indicate similar levels of satisfaction between both Vauban and Rieselfeld residents. In Vauban, 83.5\% of responses were "satisfied" and "very satisfied"; in Rieselfeld, $86.7 \%$. For both places, dissatisfaction levels in living in the two neighborhoods were between 10 and 15 percent, respectively with Rieselfeld showing around a 5\% lower dissatisfaction level.

Another corroborating question asked respondents about their "level of satisfaction with their decision" to move into these two neighborhoods (Table 6). The sum of the percentages in the 5,6 , and 7 ratings indicate a generally high level of satisfaction with the decision to move into each of the two neighborhoods with similar response percentages between the two neighborhoods86.4\% for residences in Vauban and $85.4 \%$ for Rieselfeld. Both questions on residential satisfaction, one on living there and one on their decision to move there, show very high levels of satisfaction. These data are still at the aggregate level and do not tell us the critical social factors experienced in community satisfaction.

\subsection{Level of Social Engagement in Rieselfeld and Vauban}

Besides improving the understanding of why people moved to Rieselfeld or Vauban and their level of satisfaction with living there now, the study was also inter- ested in residents' perceptions regarding the level of social engagement in the two neighborhoods (Table 7). We considered three factors as social engagement factors: the amount of social contact, influence on local decisionmaking processes, and participation in local organizations. Respondents in each of the neighborhoods were asked to rate the level of social contact (friendliness), the ability to influence local decisions (governance), and participation in local organizations (civic involvement).

The analysis looked at the responses in the top two ratings, 6 and 7 on the Likert scale for both communities. For social contacts, the combined average percentages in the 6 and 7 categories were 38.8 percent in Vauban. The combined percentage was much higher at 55.6 percent In Rieselfeld. If we include the mid-level rating (5), social contacts for Vauban rank over $50 \%$ (59.2) and $70 \%$ for Rieselfeld, we can deduce that the very high levels of satisfaction living in the two neighborhoods are not significantly influenced by knowledge of neighbors in Vauban but may be a contributing factor in Rieselfeld.

We also wanted to determine if governance or community involvement made a difference. To answer this question, respondents were asked to rate the statement "I feel I can influence decisions that affect my neighborhood" on a 1- to 7-point Likert scale. The combined scores of 6 and 7 were assessed. Results showed that

Table 5. Overall level of satisfaction with living in Rieselfeld/Vauban.

\begin{tabular}{lllllll}
\hline & Very dissatisfied & Dissatisfied & Neutral & Satisfied & Very satisfied & No answer \\
\hline Rieselfeld & $10.3 \%$ & $0.0 \%$ & $2.1 \%$ & $30.9 \%$ & $55.7 \%$ & $1.0 \%$ \\
Vauban & $15.5 \%$ & $0.0 \%$ & $1.0 \%$ & $35.0 \%$ & $48.5 \%$ & - \\
\hline
\end{tabular}

Note: Survey respondents were asked "On a scale from 1 to 5 , with 1 being 'very dissatisfied' and 5 being 'very satisfied', how satisfied overall are you with living in Vauban/Rieselfeld?".

Table 6. Level of satisfaction with moving to Rieselfeld/Vauban.

\begin{tabular}{|c|c|c|c|c|c|c|c|c|}
\hline $\begin{array}{l}\text { Satisfied with } \\
\text { moving to... }\end{array}$ & $\begin{array}{l}1 \\
\text { Very dissatisfied }\end{array}$ & 2 & 3 & $\begin{array}{l}4 \\
\text { Undecided }\end{array}$ & 5 & 6 & $\begin{array}{l}7 \\
\text { Very satisfied }\end{array}$ & $\begin{array}{l}\text { No } \\
\text { answer }\end{array}$ \\
\hline Rieselfeld & $2.1 \%$ & $1.0 \%$ & $2.1 \%$ & $4.1 \%$ & $11.3 \%$ & $16.5 \%$ & $57.7 \%$ & $2.1 \%$ \\
\hline Vauban & $4.9 \%$ & $1.9 \%$ & $1.0 \%$ & $4.9 \%$ & $8.7 \%$ & $28.2 \%$ & $49.5 \%$ & $4.9 \%$ \\
\hline
\end{tabular}

Note: Survey respondents were asked "On a scale from 1 o 8, with 1 being 'very dissatisfied' and 7 being 'very satisfied', how satisfied overall are you with your decision to move to Rieselfeld/Vauban?"

Table 7. Level of social engagement in Rieselfeld/Vauban.

\begin{tabular}{lllllllll}
\hline Rieselfeld & $\mathbf{1}$ & $\mathbf{2}$ & $\mathbf{3}$ & $\mathbf{4}$ & $\mathbf{5}$ & $\mathbf{6}$ & $\mathbf{7}$ & No answer \\
\hline Social contacts & $3.1 \%$ & $4.1 \%$ & $8.2 \%$ & $13.4 \%$ & $14.4 \%$ & $17.5 \%$ & $38.1 \%$ & $1.0 \%$ \\
Ability to influence local decisions & $7.2 \%$ & $14.4 \%$ & $21.6 \%$ & $28.9 \%$ & $11.3 \%$ & $11.3 \%$ & $2.1 \%$ & $3.1 \%$ \\
Participation in local organizations & $21.6 \%$ & $16.5 \%$ & $10.3 \%$ & $21.6 \%$ & $9.3 \%$ & $6.2 \%$ & $9.3 \%$ & $5.2 \%$ \\
\hline Vauban & $\mathbf{1}$ & $\mathbf{2}$ & $\mathbf{3}$ & $\mathbf{4}$ & $\mathbf{5}$ & $\mathbf{6}$ & $\mathbf{7}$ & No answer \\
\hline Social contacts & $1.9 \%$ & $3.9 \%$ & $14.6 \%$ & $19.4 \%$ & $20.4 \%$ & $26.2 \%$ & $12.6 \%$ & $1.0 \%$ \\
Ability to influence local decisions & $5.8 \%$ & $19.4 \%$ & $19.4 \%$ & $15.5 \%$ & $25.2 \%$ & $8.7 \%$ & $1.0 \%$ & $4.9 \%$ \\
Participation in local organizations & $30.1 \%$ & $15.5 \%$ & $9.7 \%$ & $16.5 \%$ & $5.8 \%$ & $9.7 \%$ & $4.9 \%$ & $7.8 \%$ \\
\hline
\end{tabular}

Note: Survey respondents were asked "Please rate the following statements using a scale from 1 to 7 , a) I know my neighbors on my street; b) I feel I can influence decisions that affect my neighborhood; c) Members of my household participate in formal or informal neighborhood associations or groups." 
not many residents of the two neighborhoods, $9.7 \%$ in Vauban and $13.4 \%$ in Rieselfeld, felt that they could influence decisions that would impact their neighborhood. This factor was not strong enough to explain high satisfaction rates for either neighborhood. The third factor, household participation in local community associations, was found to be lower than expected given the literature on the two neighborhoods and the interviews on the social aspects of planning the two communities. Only $14.6 \%$ of households participate actively in Vauban (ratings of 6 \& 7) and only $15.6 \%$ in Rieselfeld rated their involvement with local organizations.

The results for satisfaction with living in the two neighborhoods were expected given the increasing values of homes and the relatively long periods of time that residents stay. The high levels of social contact suggest a significant level of trust among neighbors, which is a most important feature of social capital, increasing the likelihood of cooperation that further increases trust (Dempsey, 2008, 2011). But in the two other social engagement areas, local decision-making processes and participation in local organizations, activities did not meet our expectations. At the higher end of the Likert scale (ratings 6 and 7), percentages were less than expected. While these percentages were lower than we anticipated, they may be higher than the rate of these activities in communities elsewhere in the world (Beatley, 2004; Head, 2008; Putnam, 2000). Our study did not compare findings to external communities. This is a future research area that will provide greater insight into what makes these communities good places to live.

\section{Conclusion}

This paper first addresses the question "How did the city of Freiburg establish the social dimension of sustainable neighborhood development into the planning process of Rieselfeld and Vauban" in section 2. As pointed out by the vast amount of available literature and city officials, Freiburg took advantage of local circumstances, such as early interest in the green movement among its citizens, to engage in environmentally friendly and socially just policies building up social capital and fostering social sustainability. This resulted in long-term commitments outlined in the city's local Agenda 21 in 1996 and the signing of the Aalborg Commitments in 2006.

When looking at the social dimension of sustainable development practices specifically, the city's longterm approach to planning as well as inclusion of the five big Cs-cost, comfort, control, consensus, and cooperation-for successful sustainable policy implementation and urban development were found to be a vital part of Freiburg's success. The city's focus on public outreach and citizen participation also was a decisive factor in directly establishing the social dimension of sustainable neighborhood development into the planning process of Rieselfeld and Vauban. As pointed out in section 2 , the citizen organizations established early on build a strong sense of place and community as well as a robust and diverse social fabric. Although, some circumstances are unique to Freiburg and cannot be replicated easily in other cities, other aspects of the City's approach are transferable to other municipalities looking for ways to increase not only the environmental but also social dimensions of sustainable urban development.

The analysis of the survey data in section 4 focuses on the second underlying research question "How do residents perceive the level of social engagement in the two neighborhoods, why did they move there, and are they satisfied with their decision?" The analysis first addresses the question of what drew people to Vauban and Rieselfeld. The results show positive responses to all the locational factors-Safety, Peace \& Quiet, Affordability of Housing, Quality of Schools, Sense of Community, Walkability, Energy Efficiency Households, Public Amenities, and Environmentally Friendly Design-defined in the surveys given to neighborhood residents. These factors were taken from the social dimensions' literature on sustainable urbanism and relate to the seven contributing factors to urban social sustainably this study focuses on and discussed in section 2.1. All nine of the variables are within or above the medium scale of importance to persons looking for a place to settle and live sustainably. The factors range from 4.5 to 6.0 on a 1 to 7-point rating scale where 1 is "not at all important" to 7 which means "very important" in people's decisions to move into a neighborhood.

None of the elements stands out as exceptionally or critically important for adopting the neighborhood. It is the plethora of physical and social elements that come together to create a place. This "clustering effect" highlights the consistency and reliability of all variables. A few variables do rank at the highest levels of importance within the cluster, however. Our results show "Peace \& Quiet" and "Environmentally Friendly Design" at the top of the cluster. But in what context do these two factors lead in importance? Certainly, significant pedestrianism, lack of automobiles, housing with courtyards and gardens, as well as high levels of walkability are among the factors that contribute to both peace and quiet, and environmentally friendly design.

Interestingly, a few of the nine factors are not as important to the neighborhood homebuyers as the literature would have us think. For example, safety, housing affordability, quality of schools and overall sense of community show less importance than anticipated. Despite attempts to reduce housing costs through cooperative participation in designing multiple-housing units as entry into these neighborhoods, it did not apply everywhere and was not deemed a factor of high importance. Similarly, with a population of over $50 \%$ of households in Vauban without children, the quality of schools did not emerge as an important social factor for relocation into the neighborhood.

"Environmental Friendly Design" as a factor for purchasing homes and residing in the two neighborhoods 
were words that we used to characterize the neighborhoods, but the data suggests that survey respondents did not link that term to energy efficiency or technologies, but concepts of space and place and form of the neighborhoods as well as social engagement. This is most likely due to the way the term was translated into German for the survey instrument. Only $46.6 \%$ of residents indicated that environmental factors were important to them when they purchased or rented their home. Surprisingly, $71.5 \%$ of respondents identified social factors as a principal reason for moving into the neighborhoods. These factors were generally clustered together indicating consistency across respondents.

The second half of section 4 focused on the level of satisfaction of living in either of the two neighborhoods followed by a discussion of the level of social engagement among the residents. The data show high levels of satisfaction with the decision to move into the neighborhoods and with the current quality of life in Vauban and Rieselfeld. There was congruence in attitudes between what was important to residents moving into the community and satisfaction with living there, meaning that the attributes of space and place that were important were met by living there. This congruence resulted in an average "livability satisfaction" rating of $85.2 \%$ for "satisfied" and "very satisfied" for living in the two communities.

Lastly, tested responses to measure the level of social and community engagement tell us that both communities experienced fairly solid community engagement levels if we take the percentages in the 5, 6, and 7 ratings on a 1 to 7 scale of involvement or engagement. This indicates a strong social sustainability in both neighborhoods. In terms of social cohesion or level of neighborliness, Rieselfeld residents had $70 \%$ knowledge of their neighbors while Vauban had $58.4 \%$. Using the same rating categories $(5,6$, and 7$)$, average scores for political involvement in local organizations and the ability to influence decisions were in the mid-20s. We argue that compared to other cities around the world, especially in the United States, these percentages of people engaged in sociopolitical organizations remains relatively good.

What did we learn from this case study of two neighborhoods that can provide insights to research on the social ecology of urban areas that impacts sustainable development? Satisfaction with living in a place and reinforcing its assets through social resiliency or livability can result in long-term community staying power. In both neighborhoods studied around 70 percent of residents had lived in the two neighborhoods for over ten years and continued to express high levels of "satisfaction". In general, there were few differences in preferences ratings of physical and social assets between the two communities. The key factors identified in the literature on social sustainability were also seen as important factors in these neighborhoods, and we mention these as a "cluster" of social factors explaining "satisfaction" with living there. Some factors received less influence in importance such as quality of schools in one neigh- borhood. In this case demographics were a key explanatory variable based on a much lower number of children. Overall, the levels of importance of social factors contributing to place satisfaction and staying power were not significantly different in both neighborhoods. Having a "cluster" of social factors present that were important to residents contributed significantly to place satisfaction. In fact, the survey results showed that it was these social factors that were seen as more important to place satisfaction than the physical attributes of sustainable developments.

From the findings, we surmise that residents' satisfaction levels with living in the neighborhoods are derived from environmentally friendly designs, maintaining social capital, and community engagement and participation. Importantly, these factors were developed and sought after by the original designers of the two communities. Thus, we can hypothesize that intentional, participatory design can result in both highly sustainable and livable urban areas. This hypothesis points to future research opportunities. The current study is limited in scope, focusing on two neighborhoods. Future research should also look at the relationship of Rieselfeld and Vauban with the city of Freiburg. For the two neighborhoods, the city of Freiburg, provides added value in the larger social ecology for sustainability-food markets, social interaction, education, shopping, and services. It is also the cultural hub of the region. In addition, it is likely that the survey instrument does not capture all factors that can explain what drove people to relocate as well as how satisfied and socially engaged they are nor does it cover all contributing factors to urban social sustainability outlined in Table 1 . Therefore, this study should function as a benchmark for different follow-up studies from an empirical perspective, for example by expanding the survey instrument and comparing Freiburg and its two neighborhoods to other cities.

\section{Acknowledgments}

This research was supported by ASU's School of Geographical Sciences and Urban Planning as well as the European and United States Regional and Urban Studies (NEURUS) program. Any opinions, findings, and conclusions or recommendations expressed in this material are those of the authors and do not necessarily reflect the views of the supportive organizations. We extend a special thanks to Klaus Siegel, (head of the city-appointed Rieselfeld Development Committee from 1992 to 2010), Almut Schuster (member of Stadteilverein Vauban e.V and long-term resident of Vauban), Andreas Rössler (president of BIV and long-term resident of Rieselfeld), and the residents of Freiburg's Rieselfeld and Vauban neighborhoods who participated in our survey research. The authors also want to thank the reviewers of earlier versions of this paper for their insights and comments. 


\section{Conflict of Interests}

The authors declare no conflict of interests.

\section{References}

Agyeman, J. (2005). Sustainable communities and the challenge of environmental justice. New York: New York University Press.

Ahmed, K. G. (2012). Urban social sustainability: A study of the Emirati local communities in Al Ain. Journal of Urbanism: International Research on Placemaking and Urban Sustainability, 5(1), 41-66. doi:10.1080/17549175.2012.659515

Aldous, T. (1992). Urban villages: A concept for creating mixed-use urban developments on a sustainable scale. London: Urban Villages Group.

Barlow, J., Jackson, R., \& Meikle, J. (2001). Homes to DIY for: The UK's self-build housing market in the twentyfirst century. York: Joseph Rowntree Foundation.

Barton H. (2000a). Conflicting perceptions of neighbourhood. In H. Barton (Ed.), Sustainable communities: The potential for eco-neighbourhoods (pp. 3-18). London: Earthscan.

Barton H. (2000b). The neighbourhood as ecosystem. In H. Barton (Ed.), Sustainable Communities: The potential for eco-neighbourhoods (pp. 86-104). London: Earthscan.

Beatley, T. (2004). Native to nowhere. Washington DC: Island Press.

Bramley, G., Dempsey, N., Power, S., Brown, C., \& Watkins, D. (2009). Social sustainability and urban form: Evidence from five British cities. Environment and Planning A, 41(9), 2125.

Bramley, G., \& Power, S. (2009). Urban form and social sustainability: The role of density and housing type. Environment and Planning B: Planning and Design, 36(1), 30-48. doi:10.1068/b33129

Bridger, J. C., \& Luloff, A. E. (1999). Toward an interactional approach to sustainable community development. Journal of Rural Studies, 15(4), 377-387. doi:10.1016/S0743-0167(98)00076-X

Bridger, J. C., \& Luloff, A. E. (2001). Building the sustainable community: Is social capital the answer? Sociological Inquiry, 71(4), 458-472. doi:10.1111/j.1475682X.2001.tb01127.x

Bundesministerium für Umwelt, Naturschutz, Bau und Reaktorsicherheit. (2007). Leipzig Charta zur nachhaltigen europäischen Stadt. Berlin: BMUB Presseund Informationsstab.

Burton, E. (2000). The compact city: Just or just compact? A preliminary analysis. Urban Studies, 37(11), 19692006. doi:10.1080/00420980050162184

Carley, M., \& Kirk, K. (1998). Sustainable by 2020? A strategic approach to urban regeneration for Britain's cities. London: Policy Press.

Choi. J. (2013). An analysis of area type and the availability of alternative transportation services on subjec- tive well-being: Are people happiest in cities? (Master's thesis). Massachusetts Institute of Technology, Cambridge, USA.

City of Freiburg. (2013). Mietspiegel. Freiburg: Amt für Liegenschaften und Wohnungswesen.

City of Freiburg. (2017a). Bevölkerung und Wohnen: Bevölkerungsstruktur. Retrieved from http://www. freiburg.de/pb/,Lde/207904.html

City of Freiburg. (2017b). Agenda 21 in Freiburg. Retrieved from http://www.agenda21-freiburg.de/ agenda-21-in-freiburg.html

City of Freiburg. (2017c). Die Zusammensetzung des Gemeinderats. Retrieved from http://www. freiburg.de/pb/,Lde/205876.html

Cloutier, S., \& Pfeiffer, D. (2015). Sustainability through happiness: A framework for sustainable development. Sustainable Development, 23(5), 317-327. doi:10.1002/sd.1593

Colantonio, A., \& Dixon, T. (2011). Urban regeneration \& social sustainability: Best practice from European cities. Oxford: John Wiley \& Sons.

Crowhurst Lennard, S. H., von Ungern-Sternberg, S., \& Lennard, H. L. (Eds.). (1997). Making cities livable: Wege zur menschlichen Stadt. Carmel: International Making Cities Livable Conference.

Deakin, E. (2001). Sustainable development and sustainable transportation: Strategies for economic prosperity, environmental quality, and equity (Working Paper 2001-03). Berkeley: UC Berkeley, Institute of Urban and Regional Development.

Dempsey, N. (2008). Does quality of the built environment affect social cohesion? Urban Design and Planning, 161(3), 105-114. doi:10.1680/udap. 2008.161.3.105

Dempsey, N., Bramley, G., Power, S., \& Brown, C. (2011). The social dimension of sustainable development: Defining urban social sustainability. Sustainable Development, 19(5), 289-300. doi:10.1002/sd.417

Dempsey, N., Brown, C., \& Bramley, G. (2012). The key to sustainable urban development in UK cities? The influence of density on social sustainability. Progress in Planning, 77(3), 89-141. doi:10.1016/ j.progress.2012.01.001

Department for Communities and Local Government. (2012). National planning policy framework. Retrieved from https://www.gov.uk/guidance/nationalplanning-policy-framework

Dixon, T. (2012). Creating strong communities: How to measure the social sustainability of new housing developments. Cobham: The Berkeley Group.

Drilling, M., \& Schnur, O. (Eds.). (2012). Nachhaltige Quartiersentwicklung: Positionen, Praxisbeispiele und Perspektiven. Wiesbaden: VS Verlag.

Fainstein, S. (2010). The just city. Ithaca: Cornell University Press.

Fischhoff, B., Slovic, P., Lichtenstein, S., Read, S., \& Combs, B. (1978). How safe is safe enough? A psychometric study of attitudes towards technological 
risks and benefits. Policy Sciences, 9(2), 127-152. doi:10.1007/BF00143739

Flora, J. L. (1998). Social capital and communities of place. Rural Sociology, 63(4), 481-506. doi:10.1111/j.15490831.1998.tb00689.x

Forrest, R., \& Kearns, A. (2001). Social cohesion, social capital and the neighbourhood. Urban Studies, 38(12), 2125-2143. doi:10.1080/00420980120087081

Forum Vauban. (2013). Planung \& Daten. Retrieved from https://www.vauban.de/com_admintools/themen/ 12-vauban/planung-daten

Frey, W. (2013). Freiburg green city. Freiburg: Herder.

Freytag, T., Gössling, S., \& Mössner, S. (2014). Living the green city: Freiburg's Solarsiedlung between narratives and practices of sustainable urban development. Local Environment, 19(6), 644-659. doi:10.1080/13549839.2013.868872

Galster, G., Quercia, R., \& Cortes, A. (2000). Identifying sustainable neighborhoods: An empirical exploration of threshold effects. In C. A. Brebbia, A. Ferrante, M. Rodiguez, \& B. Terra (Eds.), The sustainable city (pp. 371-380). Southampton: WIT Press.

Giddings, B., Hopwood, B., \& O’Brien, G. (2002). Environment, economy and society: Fitting them together into sustainable development. Sustainable Development, 10(4), 187-196. doi:10.1002/sd.199

Hagen, B., Middel, A., \& Pijawka, D. (2016). Global climate change risk and mitigation perceptions: A comparison of nine countries. Journal of Sustainable Development, 9(5), 214. doi:10.5539/jsd.v9n5p214

Hamiduddin, I., \& Daseking, W. (2014). Communitybased planning in Freiburg, Germany: The case of Vauban. In N. Gallent \& D. Ciaffi (Eds.), Community action and planning: Context, drivers and outcomes. Bristol: Policy Press.

Hamiduddin, I. (2015). Social sustainability, residential design and demographic balance: Neighbourhood planning strategies in Freiburg, Germany. Town Planning Review, 86(1), 29-52. doi:10.3828/tpr.2015.3

Harvey, D. (2010). Social justice and the city. Athens: The University of Georgia Press.

Head, B. W. (2007). Community engagement: Participation on whose terms? Australian Journal of Political Science, 42(3), 441-454. doi:10.1080/ 10361140701513570

Henerson, M. E., Morris, L. L., \& Fitz-Gibbon, C. T. (1987). How to measure attitudes (2nd ed.). Newbury Park, CA: SAGE.

Holden, M. (2012). Urban policy engagement with social sustainability in Metro Vancouver. Urban Studies, 49(3), 527-542. doi:10.1177/0042098011403015

Hopwood, B., Mellor, M., \& O’Brien, G. (2005). Sustainable development: Mapping different approaches. Sustainable Development, 13(1), 38-52. doi:10.1002/sd.244

Hopwood, D. (2007). Blueprint for sustainability?: What lessons can we learn from Freiburg's inclusive approach to sustainable development? Refocus, 8(3),
54-57. doi:10.1016/S1471-0846(07)70068-9

Jenks, M., \& Dempsey, N. (Eds.). (2005). Future forms and design for sustainable cities. Oxford: Architectural Press.

Jones, C., Leishman, C., \& MacDonald, C. (2009). Sustainable urban form and residential development viability. Environment and Planning A, 41(7), 1667-1690. doi:10.1068/a40265

Joubert, L. (2004). Creative communities: The arts, social responsibility and sustainable planning and development. In N. Marchettini, C. A. Brebbia, E. Tiezzi, \& L. C. Wadhwa (Eds.), The sustainable city III (pp. 473-482). Southampton: WIT Press.

Li, F., Wang, R., Paulussen, J., \& Liu, X. (2005). Comprehensive concept planning of urban greening based on ecological principles: A case study in Beijing, China. Landscape and Urban Planning, 72(4), 325336. doi:10.1016/j.landurbplan.2004.04.002

Littig, B., \& Griessler, E. (2005). Social sustainability: A catchword between political pragmatism and social theory. International Journal of Sustainable Development, 8(1/2), 65-79. doi:10.1504/IJSD.2005.007375

Luederitz, C., Lang, D. J., \& Von Wehrden, H. (2013). A systematic review of guiding principles for sustainable urban neighborhood development. Landscape and Urban Planning, 118, 40-52. doi:10.1016/ j.landurbplan.2013.06.002

McKenzie, S. (2004). Social sustainability: Towards some definitions (Working Paper No. 27). Adelaide: Hawke Research Institute, University of South Australia, Australia.

McMillan, D. W., \& Chavis, D. M. (1986). Sense of community: A definition and theory. Journal of Community Psychology, 14(1), 6-23.

Medearis, D., \& Daseking, W. (2012). Freiburg, Germany: Germany's eco-capital. In T. Beatley (Ed.), Green cities in Europe (pp. 29-64). Washington, DC: Island Press.

Mössner, S. (2015). Urban development in Freiburg, Germany-Sustainable and neoliberal? DIE ERDEJournal of the Geographical Society of Berlin, 146(2/3), 189-193. doi:10.12854/erde.v146i2-3.204

Mössner, S. (2016). Sustainable urban development as consensual practice: Post-politics in Freiburg, Germany. Regional Studies, 50(6), 971-982. doi:10.1080/00343404.2015.1102875

Mössner, S., \& Miller, B. (2015). Sustainability in one place? Dilemmas of sustainability governance in the Freiburg metropolitan region. Regions Magazine, 300(1), 18-20.

Murphy, K. (2012). The social pillar of sustainable development: A literature review and framework for policy analysis. Sustainability: Science, Practice \& Policy, 8(1), 15-29.

Nasar, J. L., \& Julian, D. A. (1995). The psychological sense of community in the neighborhood. Journal of the American Planning Association, 61(2), 178-184. doi:10.1080/01944369508975631

Newman, P., Beatley, T., \& Heather, B. (2009). Resilient 
cities: Responding to peak oil and climate change. Washington, DC: Island Press.

Nössler, B., \& de Witt, M. (1976). Wyhl: Kein Kernkraftwerk in Wyhl und auch sonst nirgends: Betroffene Bürger berichten. Freiburg: Inform-Verlag.

Putnam, R. D. (2000). Bowling alone: America's declining social capital. In L. Crothers \& C. Lockhart (Eds.), Culture and politics (pp. 223-234). New York: Palgrave Macmillan.

Rohracher, H., \& Späth, P. (2014). The interplay of urban energy policy and socio-technical transitions: The eco-cities of Graz and Freiburg in retrospect. Urban Studies, 51(7), 1415-1431. doi:10.1177/ 0042098013500360

Roseland, M. (2012). Toward sustainable communities: Solutions for citizens and their governments. Gabriola Island, Canada: New Society Publishers.

Sander, T. H. (2002). Social capital and new urbanism: Leading a civic horse to water? National Civic Review, 91(3), 213-234. doi:10.1002/ncr.91302

Scheurer, J., \& Newman, P. (2009). Vauban: A European model bridging the green and brown agendas (Case study prepared for Revisiting Urban Planning: Global Report on Human Settlements 2009).

Schwaller, E. (2012). Effects of neighborhood design on residential habits and sense of community: Testing the claims of new urbanism (Master's Thesis). Arizona State University, Tempe, AZ, USA. Retrieved from http://search.proquest.com/docview/ 1268733306/abstract/FCC9B3FAAB084474PQ/1

Seidman, K. F. (2013). Coming home to New Orleans: Neighborhood rebuilding After Katrina. Oxford: Oxford University Press.

Slovic, P., Fischhoff, B., \& Lichtenstein, S. (1984). Behavioral decision theory perspectives on risk and safety. Acta Psychologica, 56, 183-203.

Social Analysis and Reporting Division Office for National Statistics. (2001). Social capital: A review of the liter- ature. London: Office for National Statistics.

Stren, R., \& Polèse, M. (2000). Understanding the new sociocultural dynamics of cities: Comparative urban policy in a global context. In M. Polèse \& R. Stren (Eds.), The social sustainability of cities: Diversity and the management of change (pp. 3-38). Toronto: University of Toronto Press.

UK Presidency. (2005). Bristol Accord: Conclusions of ministerial informal on sustainable communities in Europe. London: The Office of the Deputy Prime Minister.

Vallance, S., Perkins, H. C., \& Dixon, J. E. (2011). What is social sustainability? A clarification of concepts. Geoforum, 42(3), 342-348. doi:10.1016/j.geoforum. 2011.01.002

Van der Ryn, S., \& Calthorpe, P. (1986). Sustainable communities. San Francisco: Sierra Club Books.

Wheeler, S. (2012). Climate change and social ecology: A new perspective on the climate challenge. New York: Routledge.

Winter, J., \& Farthing, S. (1997). Coordinating facility provision and new housing development: Impacts on car and local facility use. In S. M. Farthing (Ed.), Evaluating local environmental policy (pp. 159-179). Aldershot: Avebury.

Woodcraft, S., Hackett, T., \& Caistor-Arendar, T. (2001). Design for social sustainability: A framework for creating thriving new communities. London: The Young Foundation.

Woodcraft, S. (2012). Social sustainability and new communities: Moving from concept to practice in the UK. Procedia-Social and Behavioral Sciences, 68, 29-42. doi:10.1016/j.sbspro.2012.12.204

World Commission on Environment and Development. (1987). Our common future. Oxford: Oxford University Press.

Yiftachel, O., \& Hedgcock, D. (1993). Urban social sustainability: The planning of an Australian city. Cities, 10(2), 139-157. doi:10.1016/0264-2751(93)90045-K

\section{About the Authors}
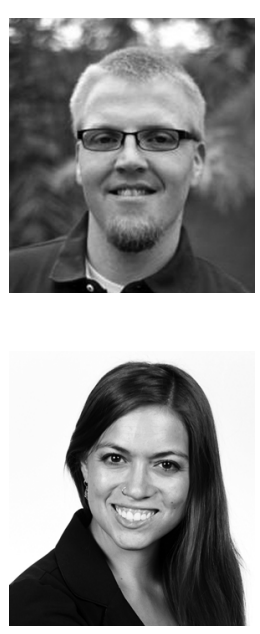

Bjoern Hagen holds a M.Sc. in Spatial and Environmental Planning from the University of Kaiserslautern, Germany, and received his Ph.D. in Environmental Design and Planning from Arizona State University. Dr. Hagen has conducted research in the areas of climate change mitigation and adaptation, public risk perception and risk communication. By studying the nature of public perceptions of global climate change in different countries and over time, his research contributes to improving climate change communication efforts to reduce greenhouse gas emissions and to increase the adaptive capacity and resiliency of urban environments.

Cara Nassar received her master's in Urban and Environmental Planning from Arizona State University in early 2017. She completed her master's research studies in international planning through the Network for European and United States Regional and Urban Studies (NEURUS) program. She held a year-long, highly competitive executive level internship in the Regional Public Transportation Authority of Phoenix. She was awarded the Arizona Transportation (AzTA) Women in Transit award in 2016, and received the Gage Davis Scholarship award for her research and studies abroad in Germany, among others. Cara Nassar is currently finishing her second Master's degree in Sustainable Solutions at Arizona State University, and contributing to research in sustainability communications. 


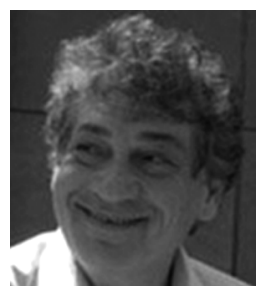

David Pijawka's research focuses on sustainable planning and design, disaster management and recovery, environmental justice, and Native American community planning. Much of Pijawka's recent work has concentrated on community projects in the U.S.-Mexico Border region and in Native American tribal communities. Pijawka served as a co-investigator on the Border Observatory Project, a five-year study tracking quality of life indicators in the U.S.-Mexico border region. He has also directed several community planning workshops for Native American tribal communities in Arizona in recent years. Pijawka is the co-author of a strategic plan for the Navajo Nation on community land use planning. Dr. Pijawka received his Ph.D in Geography from Clark University. 